2. An Inscription from the Malakhand Pass.

DEAR Sir,-Thanks to the good offices of our Hon. Secretary, Dr. R. N. Cust, we are able to publish the accompanying reproduction of an inscription, which may possibly prove to be of considerable importance. The original is in the possession of the Rev. Canon Edwards, of Exeter, who thus describes it:- "Inscription on a stone, $8 \frac{1}{3}$ in. $\times$ from $3 \frac{1}{2}$ in. to 5 in., brought from Malakhand Pass by Captain Fox-Strangways." The inscription is interesting as being a particularly clear, and apparently quite complete, specimen of a class, which has been made known to the world chiefly by the discoveries of Major Deane, and the publications of M. Emile Senart (Joumal Asiatique, 1895, pp. 332, 504), and Dr. M. A. Stein (J.A.S.B., 1898, p. 1). The language of these inscriptions, and the alphabet in which it is conveyed-particularly tantalizing from its similarity to certain well-known alphabets-have hitherto baffled all attempts at decipherment. There seems to be a consensus among scholars who have studied the matter, that the language will probably prove to be some dialect of Tūrki, and Hofrath Dr. Bühler (quoted by Dr. Stein, p. 13) has pointed out that the Turkish inscriptions from the banks of the Orkhon have more than a dozen signs in common with these; but, beyond these generalizations, no advance has been made. It is probable that we may have to wait until either a bilingual inscription is discovered, or some lucky accident gives a clue to this strange puzzle. All that ingenuity can do from an examination of the inscriptions themselves has been done by the scholars above mentioned. In the meantime it is important to publish reproductions of as many specimens as possible.

E. J. Rapson.

\title{
3. The Sambodhi in Asoka's Eighth Enict.
}

The Buddhist ideal is a subjective state to be reached, in this world, by going along an eightfold path, so called 
because of the eight good qualities or characteristics which make up its eight parts. Progress along this path is divided into four stages in which certain evil dispositions, the ten so-called Bonds, are got rid of. The Sambodhi is the insight, wisdom, intelligence, awakening, which is essential to the three higher stages of this state of Arahatship. And what is connoted by the term can best, perhaps, be understood by bearing in mind its seven constituent parts, the Sambojjhang $\bar{a}$-self-possession, investigation into the truth, energy, calm, joy, concentration, and magnanimity.

In describing the first and lowest of the four stages of the Path, it is always stated (Digha, I, 156 ; M.P.S., II, 27 ; A., II, 238, etc.) of the disciple-not that he has then attained the sambodli, he has only attained abhisamayabut that he is sambodhi-parayano. Childers (sub voce parāyano) explains this as 'having the Four Truths as his support.' But Buddhaghosa (Sum., I, 313) says: “He has the sambodhi-by which is meant that of the three higher stages-as his furthermost aim; in other words, he will attain to that."

Buddhaghosa's explanation is the only one possible in the context, and is confirmed by every other passage in the Palli Pitakas where the word sumbodhi has been traced. It never means the wisdom of a Buddha, but always the insight of the higher stages of the path to Arahatship. But it is necessary to point this out because the distinction is of the first importance for the history of Buddhism; and also because the erroneous rendering of Burnouf has been followed by Childers in the Dictionary sub voce sambodhi ('attainment of Buddhaship, Buddhahood'), and has not been corrected by any of the distinguished scholars who have discussed the meaning of Asoka's eighth edict in which the word occurs." The king there says that he "set out for the sambodhi." If this means that he had started, in his own opinion, along the line of the Pārāmitās, towards the attainment, in some future birth, of Buddhahood, then

1 See Senart, "Inscriptions de Piyadasi," 1. 186, and the other authorities referred to at 1.182 and 2. 223. 
it is most interesting and important as giving us the earliest mention of a doctrine not found in the Pali Pitakas, and entirely opposed to their view of Buddhism. But the word does not necessarily imply this, nor does the context require it. The doctrine spoken of with contempt, by the Mahāyānist doctors, as the 'Lesser Vehicle' is quite possible here, and more in accordance with all the rest of the Asoka expressions. There would seem to be no sufficient reason why we should not understand Asoka to mean that he had started, in his own opinion, along the Eightfold Path, towards the attainment, doubtless in some future birth, of Arahatship. Whether this be so or not, this is the only meaning of the word so far found in the Pitakas.

And further, this entering on the Path-the Eightfold Path to the wisdom of the Arahat-is a quite different thing from becoming a Buddhist. There are numerous passages where the very nature of the discourse held not only to upasakas, but even to bhikkhus, shows that they were not supposed to have attained as yet to the state of mind described as 'entering upon the Path.' Both the rules of the Order, and the precepts laid down for laymen, are, from the Pitaka point of view, on a different plane altogether, lower than, apart from, that of the Path. Acting up to those rules, carrying out those precepts, can never even result in 'conversion' without the awakening of the new life. It is therefore very doubtful whether the word 'conversion' should be used, in English translations of Buddhist texts, to express a man's becoming an upasalia or a bhikkhu. For though the word 'conversion' is used in English in two senses-either that of joining the outward organization of a new faith, or that of having one's eyes opened to the higher life-the second is the more accurate use of the word, and ought always to be implied in the first.

The word sambodhi-parāyano occurs in the passage first above quoted (Digha, I, 156) in the answer to the question, "What is the aim of the life of the recluse (that is, of the member of the Buddhist Order)?" Opponents and controversialists are fond of asking this question, and it is interesting 
to notice how it is answered. It is never the attainment of Buddhahood, but always (though the phraseology differs) the attainment of Arabatship. Thus, in the standing phrase used to state that so and so has become an Arahat (M.P.S., p. 60 , at the end of chapter 5, and often elsewhere), it is said he has realized the aim of the higher life (brahmacariya-pariyosanam). The Ratha-vinita and the Culla Sakuludāyi Dialogues (Nos. 24 and 79 of the Magghima Collection) lead up to the same conclusion. In the Samyutta, 4. 51, the aim is said to be the complete understanding of sorrow (dukkhassa pariñ $\tilde{n} \bar{a}$ ), and the same reply is expanded further on in the same book (4. 233) by the explanation that the way of gaining this understanding is to follow out the whole of the Eightfold Path to Arahatship. And this is repeated further on (S., 5. 6: compare Mil., 49, 101). In the Anguttara (4. 7) the object is said to be the destruction of the seven bonds, the destruction of which is precisely Arahatship.

So sambodhi-patto is used in the Sutta Nipāta, 478, 503, to describe the Arahat, of whom it is said (Itivuttaka, No. 47 , p. 42 : compare ibid., p. $11 \tau=$ A., 2.14 , and also A., 2. 200, 202 ; S.N., 765 ) that even here, in this world, he will reach up to the sambodli, the way to which is said to be the Eightfold Path (M., 1. 431, and the Dhamma-cakkappavattana Sutta, etc.). And sambodhi-parāyano, with which we started, is only another way of stating what is expressed by amata-parayano ('having the ambrosia of Arahatship as his aim ') in a Sutta, not yet traced, but quoted by Moggalliputta Tissa at Kathā Vatthu, xxii, 7. ${ }^{1}$

Of course the above is not intended to imply that the Buddha had not attained the sambodhi. He was an Arahat, and, as such, had all the graces an Arahat should have. ${ }^{2}$

T. W. Rhys Davids.

1 Compare brakma-paräyano at Mil., 234, brahmacarıya-parāyano at A., 3. 75, and dandr-parizyano at M., 1. 88 .

2 Childers thinks $s$ mbodho is merely another form of sambodhi. As the former is only found as yet in one ambiguous phrase, the discussion of its meaung would be premature. 